\title{
FACTORS RESPONSIBLE FOR EXTRAMARITAL AFFAIRS AS PERCEIVED BY MARRIED ADULTS IN LAGOS, NIGERIA
}

\author{
Maureen Ogwokhademhe, C. A. Ishola \\ University of Ilorin, Nigeria \\ E-mail: ogwokha.mc@unilorin.edu.ng
}

\begin{abstract}
The study investigates factors responsible for extramarital affairs as perceived by married adults in Lagos metropolis. Extramarital affair has been described by many authors and scholars and has been identified as one of the causes of marital problem. Descriptive survey method was employed for this study and the population is all married adults in Lagos metropolis. A total number of 200 respondents were randomly selected in Lagos metropolis and a self developed instrument titled "Factors Responsible for Extramarital Affairs Questionnaire" (FAREAQ) was used to collect relevant data from the respondents. Collected data were analyzed with both descriptive and inferential statistics. Descriptive static was employed for the personal data and research question and inferential statistic was used to analyze the hypotheses generated for the study. All hypotheses were tested at 0.05 alpha level. The major finding of the study revealed that "sex related factor" was perceived by married adults in Lagos metropolis to be the highest factor responsible for extramarital affair. Gender, age, religion and educational qualification of the factors responsible for extra marital affairs while family type of the respondents did not influence their perception. Implications of the findings to guidance and counselling therefore is that counselling (Guidance) services should be extended to families so as to educate parents on the effects of extramarital affair on marriage and on the children and also for counsellors to emphasize the effectiveness of "sex" in marital relationship. Based on the findings of the study, it was therefore recommended that counsellors should organize continuously on the mass media enlightenment programme on the various factors responsible for extramarital affairs so that couples can learn and work on themselves to secure their marriage.
\end{abstract}

Key words: extramarital affairs, factors responsible.

\section{Introduction}

Marriage is the legalizing of a relationship between a man, and a woman to which the society gives its approval. Marriage places each partner under legal and social obligations to oneself and to the society. Marriage is a union of a man and a woman who agree to live together as husband and wife (Nwoye, 1991). However, achieving success in the relationship for the benefit of the individual concerned and the society seems to be an uphill task. With this fact therefore, marriage consistently calls for adjustment as the relationship can either have a positive or negative influence on the psychological well being of husband/wife. Nwoye (1991) emphasized the fundamental ideas of marriage as;

- A union between at least one man and one woman.

- A relationship which is culturally approved. 
OF PSYCHOLOGY

IN THE $21^{\text {st }}$ CENTURY Volume 6, 2013

- An endorsement of sexual intercourse and sexual commitment between spouse, exclusive of other males and females.

- An expectation that children will be born.

- A defined mode of behaviour.

- A permanent lifelong affair.

With the analysis offered by Nwoye for what an ideal marriage entails, it is expected that following these facts accordingly will breed a hitch-free marriage but in most cases, the fundamental ideas proposed by Nwoye does not adhered to accordingly and this tend to develop in marriage some hiccups. A problem-free union is defined as a union in which husband and wife are in agreement on major issues of marriage such as handling finances, dealing with in-laws, agreements on interest, objectives and values. Harmony is an evidence of affection; and sharing is demonstrated with confidence in each other without any complaint.

Marriage is seen as a social arrangement that creates for the individual the sort of order in which he/she can express in his/her life as making sense. It is a culturally approved relationship of a man and woman in which there is cultural endorsement of sexual intercourse between the marital partners of opposite sex. Dreyer (1992) also viewed marriage as a partnership contract an escape clause. Marriage means commitment, a person in love usually wants assurance from the partner. Marriage is a sacred and permanent contract which is assumed to be enacted when two people (usually a man and a woman) decide in their own accord and in the presence of at least two witnesses to exchange vow and consent to live a life of vocation of love and sharing among each other for the purpose of promoting mutual welfare as persons in marital journey through life.

Extramarital affair on the other hand is one of the problems expressed in a problematic marriage. The concept "extra-marital" affair is seen as the marital contamination by adding a foreign substance to water down or destabilize a marriage. And Bassard (1995) defined a marital problem (problematic marriage) as a breakdown in the communication among couples which result to constant argument in forms of verbal argument, physical aggression, psychological, emotional and physical separation, all of which may lead to and end in divorce. Extramarital affair is thus described as the emotional adultery that culminates in physical sex or a long-term love affair. It is an unlawful relationship engaged in by a spouse outside his/her marriage. Extramarital affair which is related to sex problems have been identified as one of the problems in marital relationship. This is however contrary to Lee (1999) study of 6,000 couples in America. Lee study revealed that men in America engages in extra-marital affair for three reasons viz boredom, monotony and the need to boost one's ego. According to the findings of the study, this does not necessarily break up a marriage because such men eventually go back to their wives after their needs had been meet. Kenkel (1985) highlighted different kinds of extramarital affairs which are:

- One night affair.

- Emotional outbreak affair.

- Emotional sexual affair.

- Sexual Addict Affair

One night affair: It is a kind of affair that mostly happen unintentionally and there may not be a sexual affair at all.

Emotional OutbreakAffair: This generally happens when the marriage is experiencing problems and during those times, one partner turn towards a friend or companion of the opposite sex.

Emotional Sexual Affair: This is an affair whereby the unfaithful spouse does not only give the body but also the heart and there are slim chances of reunion.

Sexual Addict Affair: Is an affair in which the sexual addicts use sex over again to cause inner pain and emptiness. 
Dreyer (1992) identified five phases of extramarital affairs to be:

- Inception phase

- Recovery phase

- Pre-discovery phase

- Discovery phase.

- Resolution Phase

Inception Phase: This is the genesis of an affair which may be as a result of closeness of two opposite sex working together and seeing each other always.

Recovery Phase: This is the phase where mate struggle to unbound and rebound and come to grips with the fact that their marriage had much more glue and uniqueness than just sexual faithfulness.

Pre-discovery phase: It is a phase where by party involved are blinded to the changes taking place and the deteriorating level the affair is having on their marriage. For example, partners tend to see each other as less attractive.

Discovery Phase: This is when the affair is revealed to the cheated one how he/she gets to know is not most important. In the recovery phase, mate struggle to unbound and rebound, and come to grip with the fact that their marriage had much more glue and uniqueness than just sexual faithfulness.

Resolution Phase: The couple working on recovery slowly, re- establishes the equilibrium and depends on the intimacy of their partner.

Extramarital affair could be caused as a result of something the couple did or something they ought to do but fail to do them. There are several factors responsible for extramarital affair which include; material and psychological deprivation, break in communication, sexual incompatibility, unemployment, childlessness, differences in interest, age at marriage etc. A marriage without effective communication is liable to crawl and experience extramarital affair. Olayinka (2000) expressed that lack of adequate communication between husband and wife may lead to marriage instability. Sexual incompatibility is also another cause of an extramarital affair, it tends to foster marriage instability. Also, Akinbodunse (1996) worked on determinant of marital conflict of couples in Ondo; the findings revealed that unemployment and financial problems, of the husband has a significant role on the determination of marital conflict which is just an aspect on the causes of marital conflict. Ogundana (1998) study on causes marital instability as expressed by couples in Ilorin also found financial problem and extramarital affairs by couples to have a significant effect on marital instability. To the best of the reseracher's knowledge, for extramarital affairs which is the vacuum this study tend to fill. Olayinka expatiated further that if a wife deprives her husband sexually, he may retaliate by not having sex with her again. Thus, the husband might resorts to flirting among other women.

Effects of extramarital affairs cannot be overemphasized, in that it affects every member of the family either the one cheated or who cheats and also the children. The financial or the economic status of the family is affected. This is because the little income for the family would have to be shared to feed the family members and the one(s) outside. Man's extravagant spending for his outside lovers may prevent him from taking care of his family. A spouse involving in extramarital affairs will not have much time for his/her partner and this may lead to loneliness on the parts of the cheated one (Sexton, 1993).

However, there is no problem without a solution. A problem is best solved when the source is discovered and dealt with. Solution to extramarital affair includes the ability of the couples to understand each other's interest. Thus, the study is set out to seek answers to the following research questions: 
- What is the highest factor responsible for extramarital affairs as perceived by married adults in Lagos metropolis?

- Is there any significant difference in the factors responsible for extramarital affairs as perceived by married adults based on gender and age?

- Is there any significant difference in the factors responsible for extramarital affairs as perceived by married adults based on religion, family type and highest educational qualification?

\section{Research Hypotheses}

The following hypotheses were generated to guide the study:

- There is no significant difference in the factors responsible for extramarital affairs as perceived by married adults based on gender and age.

- There is no significant difference in the factors responsible for extramarital affairs as perceived by married adults based on religion, family type and highest educational qualification.

\section{Methodology of Research}

A descriptive survey method was adopted for this study. This survey method is defined as the approach that focused on people and their beliefs, opinion, perceptions, motivations and behaviours (Adana, 1996). This survey method is adopted because it enable(s) the researcher to obtain the opinion of the representative sample of target population that gives opportunity to infer the expression of the entire population. The population for this study comprised all married adults in Lagos metropolis (12,653 married adults) while the target population is two hundred married adults in the metropolis. Five local governments were randomly selected through dip-hat method. From these five local governments, forty (40) respondents were randomly sampled from each of the local government and the local government sampled are; Ajeromi Ifelodun, Epe, Ojo, Surulere and Kosofe local governments respectively.

The content and face validity of the instrument was ascertained by five experts in the department of Counsellor Education, University of Ilorin, Nigeria and the reliability of 0.55 confirmed through test re-test reliability revealed that the instrument is reliable to carry out the study. A self developed instrument titled "Factors Responsible for Extramarital Affairs Questionnaire" (FAREAQ) was developed for the study with a four scale Likert-type of strongly agree, agree, disagree and strongly disagree. Section A of the instrument anchor personal data of the respondents, while section B has items on factors responsible for extramarital affair which was subscaled under financial, infertility, sex-related, occupational and age-related factors.

\section{Results of Research}

Table 1. Mean and Rank Order of Factors Responsible for Extramarital Affairs.

\begin{tabular}{clcc}
\hline $\begin{array}{c}\text { Item } \\
\text { No }\end{array}$ & \multicolumn{1}{c}{ Extramarital Affairs Occurs When: } & Mean & Rank \\
\hline 1 & & & \\
\hline 16 & Husband is not financially buoyant. & 3.68 & 1 st \\
8 & Wife's or husband's work requires night duties. & 3.29 & 2 nd \\
9 & Couple produces disabled children only. & 3.09 & 3 rd \\
10 & Either of the partners do not get sexual satisfaction from the other. & 3.03 & 4 th \\
11 & Either of the partners deprives the other of sexual gratification. & 2.96 & 5 th \\
& Husband/wife wants to experience sexual variety. & 2.92 & 6 th
\end{tabular}


Husband/wife had early marriage.

Couples are in the same age bracket.

Couple unable to produce a child.

Table 1 shows that items $1,16,8,9$ and 10 were ranked $1^{\text {st }}-5^{\text {th }}$ which means that respondents level of agreement on those items are higher to factors that are responsible for extramarital affairs than items $7,20,15,13$ and 5 that ranked $16^{\text {th }}-20^{\text {th }}$ which respondents perceived to the less factors responsible for extramarital affairs.

Research Question One: What is the highest factor responsible for extramarital affairs as perceived by married adults in Lagos metropolis?

Table 2. Factors Responsible for Extramarital Affairs.

\begin{tabular}{ccccc}
\hline S/N & Fac. Res. For Extramarital Affairs & $\begin{array}{c}\text { No of } \\
\text { Resp. }\end{array}$ & Mean & Rank \\
\hline 1 & Sex Related Factors & 200 & 11.78 & 1 st \\
2 & Socio-economic Related Factors & 200 & 11.68 & 2 nd \\
3 & Occupational Related Factors & 200 & 10.60 & 3 rd \\
4 & Age Related Factors & 200 & 10.58 & 4 th \\
5 & Infertility Relator Factors & 200 & 10.33 & 5 th \\
\hline
\end{tabular}

Table 2 shows that the married adults in Lagos metropolis perceive sex-related factor to be the highest factor responsible for extramarital affair.

\section{Hypotheses Testing}

This section presents the result of the null hypotheses that were generated and tested using t-test and Analysis of Variance (ANOVA).

Hypothesis One: There is no significant difference in the factors responsible for extramarital affairs as perceived by married adults based on gender and age. 
Table 3. Mean, Standard Deviation and t-test of Married Adults' Perception on Factors Responsible for Extramarital Affairs Based on Gender and Age.

\begin{tabular}{|c|c|c|c|c|c|c|}
\hline Variable & Frequency & Mean & SD & df & $\begin{array}{c}\text { Calculated } \\
\text { t-value }\end{array}$ & $\begin{array}{l}\text { Critical } \\
\text { t-value }\end{array}$ \\
\hline \multicolumn{7}{|c|}{ Gender } \\
\hline Male & 101 & 56.58 & 5.33 & \multirow{3}{*}{198} & \multirow{3}{*}{$4.83^{*}$} & \multirow{3}{*}{1.96} \\
\hline Female & 99 & 53.39 & 3.88 & & & \\
\hline \multirow[t]{2}{*}{ Total } & 200 & & & & & \\
\hline & & Age & & & & \\
\hline Below 30yrs & 113 & 54.21 & 4.32 & \multirow{3}{*}{198} & \multirow{3}{*}{$-2.63^{*}$} & \multirow{3}{*}{1.96} \\
\hline 31yrs \& above & 87 & 56.03 & 5.45 & & & \\
\hline Total & 200 & & & & & \\
\hline
\end{tabular}

${ }^{*}$ Significant, $p<0.05$

Table 3 shows that the calculated $t$-values of 4.83 and -2.63 is greater than the critical $t$-value of 1.96 at 0.05 alpha level of significant, thus the hypothesis is rejected. It means that both gender and age of the respondents influence their perception on the factors responsible for extramarital affairs. That is, both male and female have different expression to factors responsible for extramarital affair $(56.58,53.39$ for male and female respectively) and that respondents age differences $(54.21,56.03$ respectively), influence their expressions on faction responsible for extramarital affair.

Hypothesis Two: There is no significant differences in the factors responsible for extramarital affairs as perceived by married adults based on religion, family type and educational qualification.

Table 4. Analysis of variance of Married Adults' Perception on Factors Responsible for Extramarital Affairs Based on Religion, Family Type and Educational Qualification.

\begin{tabular}{|c|c|c|c|c|c|}
\hline sSource of Variation & Sum of Squares & df & $\begin{array}{c}\text { Mean } \\
\text { Squares }\end{array}$ & $\begin{array}{c}\text { Calculated } \\
\text { F-ratio }\end{array}$ & $\begin{array}{l}\text { Critical } \\
\text { F-ratio }\end{array}$ \\
\hline \multicolumn{6}{|c|}{ Religion } \\
\hline Between Groups & 774.250 & 2 & 387.125 & \multirow{3}{*}{$18.82^{*}$} & \multirow{3}{*}{3.00} \\
\hline Within Groups & 4052.745 & 197 & 20.572 & & \\
\hline Total & 4826.995 & 199 & & & \\
\hline \multicolumn{6}{|c|}{ Family Type } \\
\hline Between Groups & 19.911 & 2 & 9.956 & \multirow{3}{*}{.408} & \multirow{3}{*}{3.00} \\
\hline Within Groups & 4807.084 & 197 & 24.401 & & \\
\hline Total & 4826.995 & & & & \\
\hline \multicolumn{6}{|c|}{ Educational Qualification } \\
\hline Between Groups & 824.090 & 4 & 206.022 & \multirow{3}{*}{$10.04^{*}$} & \multirow{3}{*}{2.37} \\
\hline Within Groups & 4002.905 & 195 & 20.528 & & \\
\hline Total & 4826.995 & 199 & & & \\
\hline
\end{tabular}

*Significant, $p<0.05$ 
Table 4 shows that the calculated f-ratios of 18.82 and 10.04 is greater than the critical f-ratio of 3.00, thus religion and educational qualification of respondents influences their perception on the factors responsible for extramarital affairs. On the other hand, the calculated f-ratio of .408 for family type of the respondents is lower than the critical f-ratio of 3.00 at 0.05 alpha level, that means, the family type of the respondents does not influence their perception on factors responsible for extramarital affairs. That is, the different religious affiliation of respondents influence their expressions on factors that are responsible for extramarital affair. For example, the way a Christian might perceived factors responsible for extramarital affair might be different from other religions. Also, educational qualification of respondents influences their perception.

Since there is a significant difference based on religion and educational qualification, Duncan Multiple Range Test (DMRT) was used as a post-hoc test to determine where the significant difference lies.

Table 5. Duncan Multiple Range Test (DMRT) of Respondents' Perceived Factors Responsible for Extramarital Affairs Based on Religion.

\begin{tabular}{lcccc}
\hline \multicolumn{1}{c}{ Religion } & Frequency & Mean & Duncan Grouping & Group \\
\hline Christianity & 84 & 57.21 & $\mathrm{~A}$ & 3 \\
Islam & 107 & 53.63 & $\mathrm{~B}$ & 2 \\
African Traditional Religion & 9 & 50.78 & $\mathrm{C}$ & 1 \\
\hline
\end{tabular}

Table 5 shows the mean scores of the three religions of the respondents that participated in the study as $57.21,53.63$ and 50.78 respectively. With the mean scores, it means that these respondents' religion influence their perception on factors responsible for extramarital affairs. And they have a different perception to the studied variable, and the significant difference noticed in ANOVA table 4 was clarified on post hoc table 5 which shows that Christianity has the highest means of 57.21 which is significantly higher than the mean score of African traditionalists (50.78).

Table 6. Duncan Multiple Range Test of Respondent's Perceived Factors Responsible for Extramarital Affairs Based on Educational Qualification.

\begin{tabular}{lcccc}
\hline Educational Qualification & Frequency & Mean & $\begin{array}{c}\text { Duncan } \\
\text { Grouping }\end{array}$ & Group \\
\hline Sec. Sch. Certificate & 19 & 58.21 & $\mathrm{~A}$ & 2 \\
Pri. Sch. Cert. & 6 & 57.67 & $\mathrm{~B}$ & 1 \\
HND/First Degree & 66 & 56.83 & $\mathrm{C}$ & 4 \\
OND/NCE, School of Nursing & 95 & 53.30 & $\mathrm{D}$ & 3 \\
Post Graduate & 14 & 52.50 & $\mathrm{E}$ & 5 \\
\hline
\end{tabular}

Table 6 shows the mean scores of the educational qualification of the respondents as 58.21, 57.67, $56.83,53.30$ and 52.50 respectively. With these mean scores, Sec. Sch. Cert. has the highest mean and post graduate has the least mean and it shows that the significant difference that was noticed on the ANOVA table 4 on the educational level of respondents was shown on the Duncan table 6 which expressed that the perception of the Sec. Sch. Cert. holders significantly different from the perception of post graduate holders on the factors responsible for extramarital affairs. That is, respondents according to their qualification perceived factors responsible for extramarital affair differently.

\section{Summary of Findings}

The study investigated factors responsible for extramarital affairs as perceived by married adults in Lagos metropolis and the findings revealed that:

- Married adults in Lagos metropolis perceived "sex related factor" to be the highest fac- 
OF PSYCHOLOGY

IN THE $21^{\text {st }}$ CENTURY Volume 6, 2013

44

tor responsible for extramarital affairs; while "infertility factor" was reported to be the least factor.

- Gender, age, religion and educational qualification of the respondents influenced their perception positively on the factors responsible for extramarital affairs.

- Family type (polygamous \& monogamous) of the respondents on the other hand did not influence their perception on the factors responsible for extramarital affairs.

\section{Discussion of Findings}

The major finding of this study revealed that "sex related factor" is perceived by married adults in Lagos metropolis to be the highest factor responsible for extramarital affairs while "infertility factor" was perceived by them to be the least factor responsible for extramarital affair. This finding might be as a general view of people's attachment to sex in marital relationship and this finding is not too far from the view of Olayinka (2000) which noted that if a wife deprives her husband sexually, he may retaliate by not having sex with her again. That means, the society view "sex" as one of the major obligation to be fulfilled in marriage.

There is a significant difference in the factor responsible for extramarital affairs as perceived by married adults based on gender. This finding showed that married adults in Lagos perceived these factors differently based on gender. That is, male, adults perceived factors responsible for extramarital affair differently from their female counterparts. This finding agrees with the view of Giwa (1996) who concluded that male predominantly involved in extramarital affairs than female.

Age of the respondents also influences their perception of factors responsible for extramarital affair. This means that different age group of married adults in Lagos state that participated in this study perceived factors responsible for extramarital affairs differently. This finding is in line with Olayinka (2000) opinion that a matured individual can cope with what marriage demand than those that are too young (youngsters). Also, Burgess and Cottrel (1990) added that the lower the age at marriage, the more unstable the marriage relationship. It means different age group view, see and perceive factors responsible for extramarital affair differently.

There is significant difference in the perception of married adults in Lagos metropolis on the factors responsible for extramarital affairs on the basis of religion. It means respondents religion influence their perception on factors responsible for extramarital affair. It further revealed that the three religious affiliated of these respondents make them to have different opinions on factors responsible for extramarital affair.

Family type of the respondents does not influence their perception on the factors responsible for extramarital affair. That is, either the respondent from polygamous or the ones from monogamous perceive factors responsible for extramarital affair the same way. Educational qualification on the other hand influences married adults in Lagos metropolis perception on the factors responsible for extramarital affair. This means that the level of education of respondents influence them to see factors responsible for extramarital affair differently. This finding is buttress by the findings of Ipaye (1995) and Imoukhome (1994) that low educational qualification can greatly contribute to the factors responsible for extramarital affairs among adults.

\section{Implications of Findings for Guidance and Counselling}

The major finding of the study revealed that respondents perceived "sex related factor" to be the major/highest factor responsible for extra marital affair. With this finding, guidance and counselling services should be extended to families so that adequate lectures be rendered to couples to see the evil in extramarital affair and work on each other and the relationship which have produced children to be a life long one that must be guided with love, affection, integrity, trustworthy that never called for a third party.

Also, counsellors must be able to emphasize the effectiveness of "sex" in marriage. Couples must be advised to know that they have to be sexually compatible with their spouses so as not to create a vacuum for interference in their relationship. 


\section{Recommendations and Conclusion}

The study investigated factors responsible for extramarital affairs as perceived by married adults in Lagos, Nigeria. And the findings revealed "Sex related factors" to be the highest factor responsible for extramarital affairs among couples; Gender, age, religion and educational qualification of the respondents influenced their perception positively on the factors responsible for extramarital affairs; also, Family type (polygamous \& monogamous) of the respondents on the other hand did not influence their perception on the factors responsible for extramarital affairs, hence the following recommendations were made:

- Professional counsellors through Counselling Association of Nigeria should organize enlightenment programmes on mass media on various factors responsible for extramarital affairs so that married couples and youngster could learn and adjust extensively to sexual obligations and challenges that are attached to marriage.

- Counselling programmes should also be designed by counsellors at higher institutions of learning to educate youths on family, sex and marital counselling so as to get their minds prepared on the functions they are expected to perform when they get into marriage and how marriage could be sustained and satisfied.

- Forum, workshops, and seminars should be organized to educate marriage couples on the effects of extramarital affair in their marriage.

\section{References}

Adana, B.S. (1996). Statistical methods for students. A demystifying approach. Ilorin: Unilorin Press.

Akinbodunse, I.A. (1996). Determinant of marital conflict as perceived by couples in Ondo. Unpublished M.Ed. Project, University of Ilorin

Bassard, J.H. (1995). Why marriage go wrong. Loskegas: Ronald Press.

Burgess, I.O. \& Cottrel, D.T. (1990). Toward a successful marriage. New York: Macmillan.

Dreyer, I.L. (1992). Sex roles and marriage among youths in the 1970's. In Navighurst, R.J. \& Dreyer, P.H. (Eds.) Youth. Seventy-forth year book of the National Society for the Study of Education. Chicago: University of Chicago Press.

Giwa, O. W. (1996). Marital Instability. Oyo: Sterling Press

Ipaye, B. (1995). Guidance and counselling in Nigerian schools. Ilorin: Chayoobi Publishers and Printers.

Imoukhome, M.O. (1994). Success in marriage. Auchi: Lead Venture.

Kenkel, F.W. (1985). The family in perceptive. New York: Macmillan.

Lee, W.K. (1996). Development of moral thought, feeling and behaviour. American psychologist, 34 (10) $956-966$.

Nwoye, A. (1991). Marriage and family counselling. Jos: Fab Anieh (Nig.) Ltd.

Ogundana, J.S. (1998). Factor responsible for marital instability as expressed by couples in Ilorin. Unpulished project, University of Ilorin.

Olayinka, M.S. (2000). Sex education and marital guidance. Yaba: Lantern books.

Sexton, L. (1993). The individual marriage and family ( $8^{\text {th }}$ Ed.). Belmont: Wordsworth Publishing Co.

\section{Appendix}

\section{FACTORS RESPONSIBLE FOR EXTRAMARITAL AFFAIRS}

Kindly rate the item as they appear to you by ticking $(\sqrt{ }$ ) each item in order of importance, using the following keys: 
ISSN 2029-8587

PROBLEMS

OF PSYCHOLOGY

IN THE $21^{\text {st }}$ CENTURY Volume 6, 2013
46

$\begin{array}{lll}\text { Strongly Agree } & - & S A \\ \text { Agree } & - & A \\ \text { Disagree } & - & D \\ \text { Strongly Disagree } & - & S D\end{array}$

\begin{tabular}{|c|c|c|c|c|c|}
\hline $\mathrm{S} / \mathrm{N}$ & Extramarital Affairs Occurs When: & SA & A & D & SD \\
\hline A. & Socio-Economic Related Factors & & & & \\
\hline 1. & Husband is not financially buoyant. & & & & \\
\hline 2 & Wife alone maintain the family financially. & & & & \\
\hline 3 & Wife earns more than husband. & & & & \\
\hline 4 & Husband does not care for his wife financially. & & & & \\
\hline B. & Infertility Related Factors & & & & \\
\hline 5 & Wife unable to bear children. & & & & \\
\hline 6 & Husband is unable to produce a child. & & & & \\
\hline 7 & Couple unable to produce a child. & & & & \\
\hline 8 & Couple produces disabled children only. & & & & \\
\hline C. & Sex Related Factors & & & & \\
\hline 9 & Either of the partners do not get sexual satisfaction from the other. & & & & \\
\hline 10 & Either of the partners deprives the other of sexual gratification. & & & & \\
\hline 11 & Husband/wife wants to experience sexual variety. & & & & \\
\hline 12 & Husband is impotent. & & & & \\
\hline D. & Occupational Related Factors & & & & \\
\hline 13 & Husband is too busy with his work. & & & & \\
\hline 14 & Wife is always tired after her day's work. & & & & \\
\hline 15 & Either of the partner's work require travelling always. & & & & \\
\hline 16 & Wife's or husband's work requires night duties. & & & & \\
\hline E. & Age Related Factors & & & & \\
\hline 17 & Couples are in the same age bracket. & & & & \\
\hline 18 & Husband/wife had early marriage. & & & & \\
\hline 19 & Husband/wife is too young for the spouse. & & & & \\
\hline 20 & Husband/wife is too old for the spouse. & & & & \\
\hline
\end{tabular}

Advised by Irena Gailiene, SMC "Scientia Educologica", Lithuania

Received: January 07, 2013

Accepted: February 28, 2013 